\title{
Absence of Wharton's jelly around an umbilical artery
}

\author{
Mouhamadou Wade*, Mamour Gueye, Aissatou Mbodji, Mame D. Ndiaye
}

Phillipe Maguilen SENGHOR Health Centre: BP 29026, Cheikh Anta DIOP University, Dakar, Senegal

Received: 14 November 2021

Accepted: 04 December 2021

\section{*Correspondence:}

Dr. Mouhamadou Wade,

E-mail: wade200903kia@hotmail.fr

Copyright: ( ) the author(s), publisher and licensee Medip Academy. This is an open-access article distributed under the terms of the Creative Commons Attribution Non-Commercial License, which permits unrestricted non-commercial use, distribution, and reproduction in any medium, provided the original work is properly cited.

\begin{abstract}
Wharton's jelly is a mucoid, avascular and connective tissue which plays the role of umbilical vessels protection. Its absence exposes to poor neonatal outcomes or fetal death. We report a rare case of Absence of Wharton's Jelly, diagnosed by examination of the placenta the examination with a live fetus.
\end{abstract}

Keywords: Umbilical cord, Absence of Wharton jelly, Neonatal outcome

\section{INTRODUCTION}

Wharton's jelly is a slack mucoid connective tissue that envelops and protects the blood vessels of the umbilical cord from compression and torsion that may occur in the uterus with fetal movement. ${ }^{1}$ The absence of Wharton's jelly is an exceptional situation with a few rare cases described in the literature..$^{2-8}$ This situation, while rare, can cause acute fetal distress and even perinatal death due to compression of unprotected vessels. We report a case of absence of Wharton's jelly around an umbilical artery.

\section{CASE REPORT}

A 34-year-old primipara was admitted with 43 weeks' gestation. Her assessment including ultrasound revealed hypertension, a nuchal cord with severe oligohydramnios. A caesarean section was performed. We delivered a male newborn of 3150 grams with an Apgar score of 6/10 at the first minute. Careful placental examination showed a partial absence of Wharton's jelly in the middle third of the umbilical cord with an umbilical artery that was exposed outside the cord as illustrated in Figure 1. The cord length was $68 \mathrm{~cm}$ with a paracentral insertion.

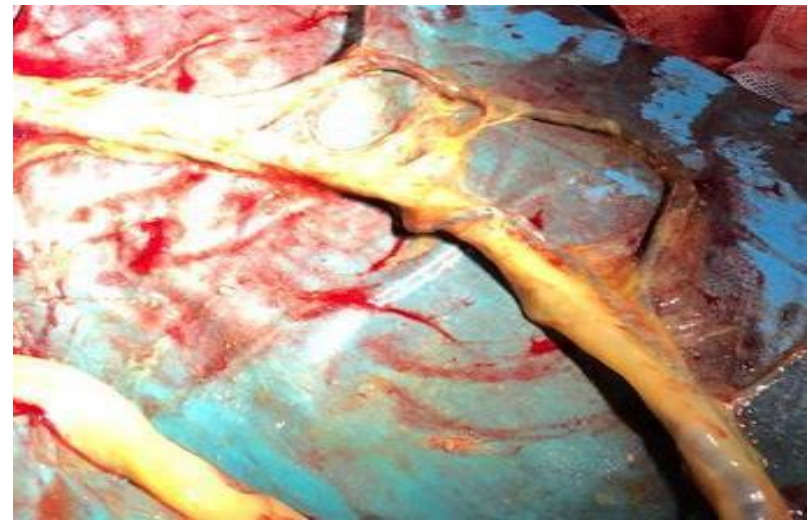

Figure 1: Absence of Wharton's jelly in the middle third of the umbilical cord.

\section{DISCUSSION}

The umbilical cord is a fetal tissue structure of allantoic origin which serves as a conduit for the transport of oxygen, nutrients and waste products between the embryo or fetus and the placenta, and thus the maternal bloodstream. It resembles a white, twisted, more or less translucent tube with an average length of 35 to $50 \mathrm{~cm}$ at 
birth. Its structure is simple, composed of two arteries and a vein enveloped in connective tissue, and covered by a thin epithelium on the exterior. ${ }^{9}$

Embryologically, the umbilical cord is constituted when the embryonic pedicle, the vitelline duct and the umbilical coelom are joined by the expanding amnion between the $4^{\text {th }}$ and $8^{\text {th }}$ week. This expansion forms a tube constituted by the amniotic membrane, enclosing the embryonic pedicle, the umbilical coelom and the vitelline duct. In the $3^{\text {rd }}$ month, the evolution will lead to the extension and reduction of the structures (vitelline duct, umbilical vesicle, the allantois which obliterates to form the ouracus or median umbilical ligament in adults). Only the embryonic pedicle stays containing the umbilical vessels ( 2 arteries, 1 vein), covered by a thin layer of amniotic epithelium. The conjunctive tissue (from the extraembryonic mesoblast) of the embryonic pedicle, first described by Thomas Wharton in 1656 is called Wharton's jelly. It is a slack mucoid tissue composed mainly of interconnected collagen fibres, glycosaminoglycans (GAGs) especially hyaluronic acid and a network of glycoprotein microfibrils. ${ }^{1}$

It is elastic, avascular and highly hydrated. It gives the cord its tonicity. The degree of hydration depends on the osmolarity of the amniotic fluid. Its role is to envelop and protect the umbilical vessels from possible pressure.

The absence of Wharton's jelly may be due to degeneration of the conjunctive tissue around the vessels or incomplete fusion of the amniotic membrane and the umbilical cord mesenchyme during early development or to hypoplasia of the amniotic membrane with a secondary defect. ${ }^{5}$

Complications of this anomaly are particularly neonatal, from restricted intrauterine growth to in utero fetal death in severe forms. ${ }^{4,7,8,10}$ The absence of Wharton's jelly is also correlated with the occurrence of a low Apgar score at birth as was the situation in our case. ${ }^{4,5}$ Some clinical situations such as hypertension in pregnancy, smoking, prematurity and over term would expose to quantitative alterations of Wharton's jelly. ${ }^{11,12}$

The differential diagnosis will be made with some anomalies of umbilical cord insertion such as "insertion funiculi furcata" in which the cord insertion site is normal but, before insertion, the vessels lose their protective Wharton's jelly envelope. The vessels thus ramify before reaching the placental surface. In velamentous insertion, the umbilical cord is inserted into the membranes and the umbilical vessels remain unprotected for some distance before reaching the placenta. ${ }^{7}$

This case highlights the importance of meticulous examination of the placenta and its adnexa because, although rare, the absence of Wharton's jelly is associated with high perinatal morbidity and mortality. Thus, a meticulous examination of the umbilical cord, which is systematic, must not be separated from the examination of the fetus or the newborn, in particular for fetal deaths and pre-, per- and post-partum deaths, most often related to placental pathology.

\section{CONCLUSION}

Wharton's jelly is a tissue that supports and protects the umbilical cord vessels against mechanical compression that may occur in utero. Its absence can lead to compression of the vessels, thus hindering maternal-fetal blood circulation, leading to perinatal complications that can be fatal for the fetus.

\section{Funding: No funding sources Conflict of interest: None declared Ethical approval: Not required}

\section{REFERENCES}

1. Chasnoff IJ, Fletcher MA. True knot of the umbilical cord. Am J Obstet Gynecol. 1977;127:425-7.

2. Bergman P, Lundin P, Malmstrom T. Mucoid degeneration of the Wharton's jelly: an umbilical cord threatening foetal life. Acta Obstet Gynecol Scand. 1961;40:372-8.

3. Thomson LL, Hoo JJ. Linear disruption of umbilical cord: a rare anomaly of the cord associated with acute fetal distress and perinatal death/profound psychomotor retardation. Am J Med Genet. 1996;62:348-9.

4. Trivedi S, Ratanoo L, Purohit S, Rastogi P. Absence of Wharton's jelly: an association with feto-maternal morbidity. Int J Reprod Contracept Obstet Gynecol. 2020;9(3):1318-20.

5. Kulkarni ML. Absence of Wharton's Jelly around the umbilical arteries. Indian J Pediatr. 2007;74(8):7879.

6. Oliveira CC, Dufloth RM, Coelho KIR. Absence of Wharton's jelly: case report. J Bras Patol Med Lab. 2014;50(6):452-5.

7. Labarrere C, Sebastiani M, Siminovich M, Torassa E, Althabe O. Absence of Wharton's jelly around the umbilical arteries: an unusual cause of prenatal mortality. Placenta. 1985;6:555-9.

8. Damascenoa EB, de Limab PP. Wharton's Jelly absence: a case of stillbirth. Autopsy Case Rep. 2013;3(4):43-7.

9. Padykula HA. The Human Placenta. In: Weiss L, editor. Cell and Tissue Biology. Urban and Schwarzenberg, Inc. 1988;899-928.

10. Filiz A, Rahine B, Keskin HL, Esra AK. Positive correlation between the quantity of Wharton's jelly in the umbilical cord and birth weight. Taiwan J Obstet Gynecol. 2011;150:33-6.

11. Silver RK, Dooley SL, Tamura RK, Depp R. Umbilical cord size and amniotic fluid volume in prolonged pregnancy. Am J Obstet Gynecol. 1987; $157: 716-20$. 
12. Barbieri C, Cecatti JG, Surita FG, Costa ML, Marussi EF, Costa JV. Area of Wharton's jelly as an estimate of the thickness of the umbilical cord and its relationship with estimated fetal weight. Reprod Health. 2011;8(37-7).
Cite this article as: Wade M, Gueye M, Mbodji A, Ndiaye MD. Absence of Wharton's jelly around an umbilical artery. Int J Reprod Contracept Obstet Gynecol 2022;11:259-61. 